\title{
Inbreeding depression in self-incompatible and self-compatible populations of Leavenworthia alabamica
}

\author{
JW Busch \\ Department of Biology, Indiana University, 1001 E 3rd St Bloomington, IN, USA
}

\begin{abstract}
Inbreeding depression is one of the leading factors preventing the evolution of self-fertilization in plants. In populations where self-fertilization evolves, theory suggests that natural selection against partially recessive deleterious alleles will reduce inbreeding depression. The purpose of this study was to evaluate this hypothesis by comparing the magnitude of inbreeding depression in self-incompatible and self-compatible populations of Leavenworthia alabamica. Within-population crosses were conducted to compare the quantity and quality of offspring produced by outcrossing and selffertilization. These progeny were grown in a common greenhouse and inbreeding depression was measured in germination, survival, biomass, transition rate to flowering, flower number, petal length, pollen grains/anther, pollen viability, and ovule number. In comparison to outcrossing,
\end{abstract}

self-fertilization led to the production of fewer and smaller seeds within self-incompatible populations. Moreover, inbreeding depression was observed in eight of 11 offspring traits within self-incompatible populations of $L$. alabamica. In contrast, there was significant inbreeding depression only in flower number within self-compatible populations. The results of this study are consistent with the idea that selffertilization selectively removes partially recessive deleterious alleles causing inbreeding depression in natural plant populations. However, in plant species such as L. alabamica where self-compatibility may evolve in small populations following long-distance dispersal, declines in inbreeding depression may also be facilitated by genetic drift. Heredity (2005) 94, 159-165. doi:10.1038/sj.hdy.6800584 Published online 24 November 2004

Keywords: deleterious mutations; genetic drift; genetic load; purging; self-fertilization

\section{Introduction}

Self-fertilization has an innate transmission advantage that should lead to the elimination of cross-fertilization because selfing individuals pass on an extra copy of their chromosomes through seeds (Fisher, 1941). However, the initial spread of genes for self-fertilization can be halted by inbreeding depression, or the lowered viability and fecundity of selfed plants (Lloyd, 1979; Lande and Schemske, 1985; Charlesworth et al, 1990; Jarne and Charlesworth, 1993). Genetic models have explored the conditions favoring the spread of genes for self-fertilization in cross-fertilizing populations. In general, rates of self-fertilization will increase in populations whenever selfed plants are at least half as fit as outcrossed plants, if genetic associations between fitness loci and selfing-rate modifier loci are not considered (Lande and Schemske, 1985; Campbell, 1986; Charlesworth et al, 1990; Uyenoyama and Waller, 1991a, b; Lloyd, 1992).

Evidence suggests that inbreeding depression is caused mainly by the expression of partially recessive deleterious alleles in the homozygous state (Dudash and Carr, 1998; Charlesworth and Charlesworth, 1999; Willis, 1999). The evolution of self-fertilization should lower the

Correspondence: JW Busch, Department of Biology, Indiana University, 1001 E. 3rd St Bloomington, IN 47405, USA.

E-mail: jbusch@bio.indiana.edu

Received 2 January 2004; accepted 15 July 2004; published online 24 November 2004 equilibrium frequency of lethal and sublethal mutations that are nearly recessive because these alleles are exposed to natural selection in the homozygous state (Lande and Schemske, 1985; Charlesworth et al, 1990; Byers and Waller, 1999). This hypothesis has been tested by forcibly self-fertilizing naturally outcrossing families of plants for several generations (Barrett and Charlesworth, 1990; Carr and Dudash, 1997; Dudash et al, 1997; Willis, 1999) or by comparing populations or lineages of plants that have divergent rates of selffertilization in natural populations (Holtsford and Ellstrand, 1990; Carr and Dudash, 1996; Johnston and Schoen, 1996; Fishman, 2001; Takebayashi and Delph, 2001). Results of these studies suggest that inbreeding depression may be reduced by self-fertilization, although purging may not always occur in response to periods of inbreeding (Byers and Waller, 1999).

Leavenworthia alabamica is an ideal species in which to test the idea that self-fertilization reduces inbreeding depression in natural plant populations (Lloyd, 1965). In this species, there is variation among populations in the prevalence of self-incompatibility. In particular, selfincompatibility predominates at the center of the species range and self-compatibility occurs in smaller populations at the border of the species range (Lloyd, 1965). Individuals within self-compatible populations produce smaller flowers, have lower pollen to ovule ratios, and produce a greater proportion of fruit through autonomous self-fertilization (Lloyd, 1965; Busch, unpublished data). There is likely to have been a history of natural 
selection in these populations to circumvent the ancestral sporophytic self-incompatibility reaction found throughout the Brassicaceae and the genus Leavenworthia (Lloyd, 1967; Bateman, 1955). The purpose of this experiment was to test the hypothesis that the evolution of selfcompatibility in L. alabamica is associated with reductions in the genetic load causing inbreeding depression.

\section{Methods}

\section{Study system}

L. alabamica Rollins (Alabama glade cress; Brassicaceae) is a winter annual endemic to the limestone cedar glades of the Moulton Valley in northern Alabama (Rollins, 1963). These cedar glades are typified by exposed and slowly eroding beds of limestone that are covered with a thin and moist layer of soil (Baskin et al, 1995). Seed germination occurs in the late fall following a long period of summer desiccation required to break dormancy. Flowering occurs from early March until the middle of April. Seeds mature within siliques on maternal plants in the early summer. There is likely to be limited pollen dispersal between populations because of the short flight distances of native pollinators (Andrena spp. and Halictus ligatus) and the relatively large distances between cedar glades. Seed dispersal is greatly limited because seeds are passively dispersed following maturation. Nevertheless, the most likely form of gene flow between populations is thought to occur following the dispersal of seeds by rare flooding events (Lloyd, 1965).

\section{Seed collection and growth of parental plants}

Attempts were made during the spring of 2002 to locate the naturally occurring populations described by Lloyd (1965). Populations with high rates of autonomous selffertilization, small petal size, and low pollen number should have long histories of inbreeding (Byers and Waller, 1999). In this study, I collected seed from five large, cross-fertilizing populations: Hatton $\left(34.50993^{\circ} \mathrm{N}\right.$, $\left.87.44204^{\circ} \mathrm{W}\right)$, Isbell $\left(34.45725^{\circ} \mathrm{N}, 87.75298^{\circ} \mathrm{W}\right)$, Newburg $\left(34.47049^{\circ} \mathrm{N}, \quad 87.57300^{\circ} \mathrm{W}\right)$, Tharptown $\left(34.59327^{\circ} \mathrm{N}\right.$, $\left.87.57198^{\circ} \mathrm{W}\right)$, Waco $\left(34.47866^{\circ} \mathrm{N}, 87.62746^{\circ} \mathrm{W}\right)$ and five small, self-fertilizing populations: Huckaby Bridge $\left(34.34532^{\circ} \mathrm{N}\right.$, $\left.86.95074^{\circ} \mathrm{W}\right)$, Landersville $\left(34.44783^{\circ} \mathrm{N}, 87.39458^{\circ} \mathrm{W}\right)$, Lebanon $\left(34.35911^{\circ} \mathrm{N}, \quad 86.97309^{\circ} \mathrm{W}\right), \quad$ Russellville $\left(34.53898^{\circ} \mathrm{N}\right.$, $\left.87.66992^{\circ} \mathrm{W}\right)$, and Tuscumbia $\left(34.70833^{\circ} \mathrm{N}, 87.83132^{\circ} \mathrm{W}\right)$; (For details, see Lloyd, 1965). The populations used in this study were sampled from the entire species range of L. alabamica and represent all of the known variation in inbreeding. Approximately two siliques (6-26 seeds) were collected from 50 randomly chosen maternal plants in each of the 10 populations and placed in single envelopes. However, in the very small Russellville population, seeds were only collected from 25 maternal plants in order to assure that my efforts did not drive this isolated population closer to extinction. These seeds were later grown in a greenhouse and used as parents in a crossing design.

Seed envelopes were placed in a $30^{\circ} \mathrm{C}$ oven for 5 days and then stored at $22^{\circ} \mathrm{C}$ for 1 month to break seed dormancy. Seeds from each maternal family were placed on $4.25 \mathrm{~cm}$ diameter filter paper and placed within small Petri plates. These dishes were maintained in an incubator with $14 \mathrm{~h}$ days $\left(15^{\circ} \mathrm{C}\right)$ and $10 \mathrm{~h}$ nights $\left(12^{\circ} \mathrm{C}\right)$, and were moistened daily with $3 \mathrm{ml}$ of autoclaved water. These plants were then grown in a common greenhouse to minimize any potential environmental maternal and paternal effects that would influence the offspring performance. Seedlings were transplanted into 3 in. pots containing a 1:1 ratio of MetroMix (Scotts-Sierra Horticultural Products, Marysville, OH, USA) and sterilized soil following the emergence of both cotyledons. Plants received $14 \mathrm{~h}$ of artificial light in the Indiana University greenhouse to promote flowering.

\section{Crossing design and greenhouse experiment}

Plants were used as parents in a crossing design to quantify the fitness effects of outcrossing and selfing. Outcrossed and selfed offspring were generated by outcrossing and forcibly self-fertilizing plants in all populations, respectively. Outcrossed offspring were produced by using randomly chosen pollen donors from within populations. To successfully produce selfed offspring, it was necessary to circumvent the self-incompatibility system active in some populations through budpollination. By forcing styles to accept pollen before flowers open, bud-pollinations allow self pollen tubes to evade detection by maternal style proteins that normally inhibit the germination of related pollen grains after flowers have opened (Bateman, 1955). Bud-pollinations were used in all crosses to ensure that flower damage would not be responsible for the reduced performance of self-fertilized offspring (Cabin et al, 1996). Overall, a total of 435 families were generated by outcrossing and selfing.

Each morning, flowers with visible petal emarginations were chosen for bud-pollinations. All of the sepals, petals, and anthers were then removed with forceps from the bud of the ovule parent. Pollen parents were selected haphazardly, with the restriction that each plant was used as a pollen donor no more than three times. Following pollen transfer, the date of bud-pollination and the identity of the pollen donor were recorded for each flower. Marked fruits were allowed to mature for 1 month and were then collected for storage. These seeds were put in envelopes, placed in a $30^{\circ} \mathrm{C}$ oven for 1 week, and then stored at $22^{\circ} \mathrm{C}$ for 3 months to ensure that seeds broke their natural dormancy. The number of seeds produced by outcrossing and self-fertilization were counted and weighed to the nearest $0.001 \mathrm{mg}$.

Families of seeds from each cross combination were given a random number to ensure that biases could not influence the measurement of performance traits. Seeds were germinated during March of 2003 as described for parental plants. Dates of germination were recorded on a daily basis within all families. When germination rates stopped increasing within families, seedlings were selected for transplantation. To avoid potential biases in selection of plants, the three most centrally located seedlings within a Petri plate were chosen, although there were often less than three germinated seeds in a family. In such situations, every seedling was transplanted. Seedlings were placed in 3 in. pots containing a 1:1 mixture of MetroMix and sterilized soil. Plants were watered twice daily and received more than $14 \mathrm{~h}$ of natural light to promote flowering.

Survival was recorded daily while plants matured in the greenhouse. The date of flowering was recorded as 
the day when the first flower opened on a plant. Days to flowering were measured as the number of days between germination and the opening of the first flower. The few plants that failed to successfully make the transition from the vegetative rosette to flowering were recorded as producing zero flowers. The number of flowers produced in the first 2 weeks of the flowering period was recorded for all individuals. Flowers were removed on a daily basis to ensure they were not counted more than once. At the end of the first month of flowering, the aboveground biomass of plants was harvested, excluding flowers and fruits. Plants were placed in envelopes, dried in a $60^{\circ} \mathrm{C}$ oven for 2 weeks, and weighed to the nearest $0.001 \mathrm{~g}$.

All floral traits were measured on the third flower produced by plants. Petal length was measured with digital calipers to the nearest $0.01 \mathrm{~mm}$. Pollen was collected in two ways to determine the quantity and quality of male gametes. Pollen was collected in the morning immediately following anther dehiscence. One of the four paired anthers was placed in a vial for pollen counting, while another was used for viability estimation. The number of pollen grains was estimated by using the Elzone $280^{\circ}$ automated particle counter. Pollen viability was estimated through the use of Alexander's stain, which colors viable pollen grains red while leaving inviable pollen grains blue (Kearns and Inouye, 1993). Viability scores were carried out by tapping single anthers onto plain glass slides three times to release adequate pollen grains. Using a medicine dropper, about $10 \mu \mathrm{l}$ of Alexander's stain was added to the slide and a cover slip was placed over the sample. Samples were then briefly warmed over a Bunsen burner flame to catalyze the coloring of viable pollen grains. Counts of inviable and viable pollen grains were performed using a light microscope. For each sample, at least several hundred pollen grains were counted to ensure that this trait was accurately measured. Female gametes were measured by cutting open the pistil with a dissecting needle and counting the number of enlarged ovules under a dissecting microscope.

\section{Estimates of lifetime male and female fitness}

The values for traits measured on all the individuals of a family were combined to generate family averages. Although many traits describe aspects of phenotype (eg biomass), some traits are direct components of survival and reproduction (eg flower number). It is possible to combine these traits to generate estimates of lifetime male and female fitness for families (eg Willis, 1999). Male gamete production was calculated as follows: (germination rate) $\times($ survival rate $) \times($ flower number $)$ $\times$ (pollen number/anther $) \times(\%$ pollen viability $)$. As a consequence, this composite value estimates the number of viable pollen grains produced, on average, over the lifetime of a plant. In a similar fashion, estimates of female gamete production were obtained for plants: (germination rate) $\times$ (survival rate) $\times$ (flower number) $\times$ (ovule number/flower). This value is a measure of the number of ovules produced over the lifetime of a plant.

\section{Inbreeding depression estimates}

There was often inadequate germination within families and populations of both types of progeny (ie outcrossed and selfed) to accurately estimate lineage or populationspecific measures of inbreeding depression. However, it was possible to pool populations according to their mating system to determine the effect of long-term inbreeding on fitness. Therefore, outcrossed $\left(w_{\mathrm{o}}\right)$ and selfed $\left(w_{\mathrm{s}}\right)$ averages for all traits were pooled within self-incompatible and self-compatible populations, respectively. Inbreeding depression was calculated as $1-\left(w_{\mathrm{s}} / w_{\mathrm{o}}\right)$ when selfed offspring had lower trait values than outcrossed progeny. In contrast, inbreeding depression was calculated as $\left(w_{\mathrm{s}} / w_{\mathrm{i}}\right)-1$ when trait values of selfed plants exceeded that of outcrossed individuals (Agren and Schemske, 1993). In all cases except for the trait 'days to flowering,' larger values translate into greater levels of performance. For this trait, longer times to flowering translate into fewer reproductive opportunities within natural populations (O'Neil, 1997). Consequently, values of this trait were inversely transformed to produce estimates of 'transition rate to flowering.' This transformed trait describes the rate at which plants make the transition from the vegetative to the reproductive state.

\section{Predictions and analyses}

Self-fertilization should strongly influence inbreeding depression because it exposes a greater fraction of partially recessive deleterious alleles to natural selection in the homozygous state. Therefore, there are two $a$ priori predictions for the magnitude of inbreeding depression observed in populations: (1) self-incompatible populations should have inbreeding depression for most traits; and (2) self-compatible populations should have relatively low levels of inbreeding depression because deleterious alleles have been purged by natural selection. Consequently, I evaluated the null hypothesis of no difference between outcrossed and selfed trait averages independently within these two types of populations using planned comparisons (Sokal and Rohlf, 1995). The means of outcrossed and selfed trait averages were computed and compared using $t$-tests with one-sided significance tests. Although most traits were normally distributed, several traits had to be analyzed using nonparametric methods because of their highly skewed distributions towards lower values. In particular, comparisons of outcrossed and selfed means for germination rate, survival rate, lifetime male fitness, and lifetime female fitness were conducted using Mann-Whitney $U$ test for difference in rank location (Sokal and Rohlf, 1995). As for the parametric tests, the null hypotheses were evaluated with one-sided tests of significance. Analyses were conducted in SPSS (version 11.5; Norusis, 2000).

\section{Results}

Within self-incompatible populations, self-fertilized seeds were smaller (mass $=1.22 \mathrm{mg}$ ) compared to outcrossed seeds (mass $=1.34 \mathrm{mg}$; Table 1 ). Self-fertilization also led to the production of $48 \%$ fewer seeds in these populations (Table 1). Self-incompatible populations exhibited significant inbreeding depression in germination rate, biomass, flower number, petal length, pollen viability, and lifetime male and female fitness (Figure 1; Tables 2 and 3). There was also marginally significant inbreeding depression for survival rate in these popula- 
Table 1 The number and mass of seeds produced by outcrossing and self-fertilization in self-incompatible (SI) and self-compatible (SC) populations

\begin{tabular}{lccccc}
\hline Seed trait & $\begin{array}{c}\text { Mating } \\
\text { system }\end{array}$ & Outcrossed & Selfed & T-statistic & $\mathrm{N}$ \\
\hline $\begin{array}{l}\text { Seed number/ } \\
\text { silique }\end{array}$ & SI & 5.04 & 2.63 & $12.564^{* * *}$ & 242 \\
& SC & 7.10 & 7.30 & 0.777 & 195 \\
Seed mass (mg) & SI & 1.34 & 1.22 & $2.012^{*}$ & 241 \\
& SC & 1.20 & 1.28 & 1.424 & 195 \\
\hline
\end{tabular}

All crosses were conducted by using bud pollinations. $N$ represents the number of outcrossed and selfed families used in analyses. Asterisks denote significant differences between selfed and outcrossed seeds $\left({ }^{*} P<0.05 ;{ }^{* * *} P<0.001\right)$. tions $(t=1.535 ; \mathrm{df}=150 ; P=0.063)$. Inbreeding depression values were positive for all traits with the exception of pollen grains/flower, which was slightly negative $(\delta=-0.02 ;$ Table 2$)$. There were large amounts of inbreeding depression in both male and female fitness $(\delta=0.54)$. The only traits for which there was no significant inbreeding depression in self-incompatible populations were transition rate to flowering, pollen number per anther, and ovule number per flower.

There were no significant differences in the size or number of seeds produced by outcrossing or selffertilization in self-compatible populations (Table 1). Within self-compatible populations, there was marginally significant inbreeding depression $(\delta=0.14)$ in flower number caused by forced self-fertilization $(t=1.583$; a

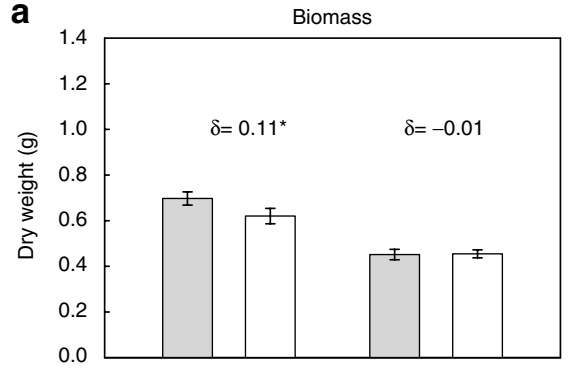

c
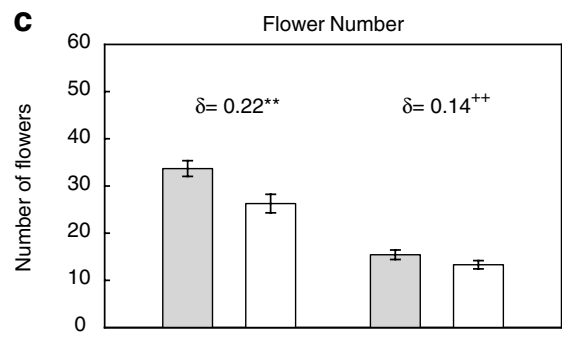

e
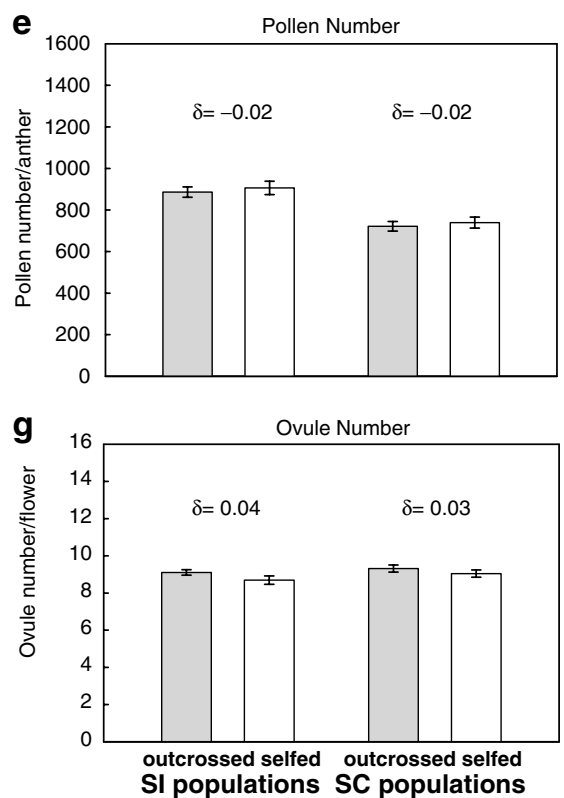

b

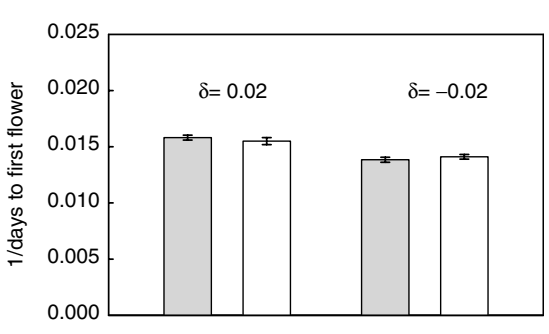

d
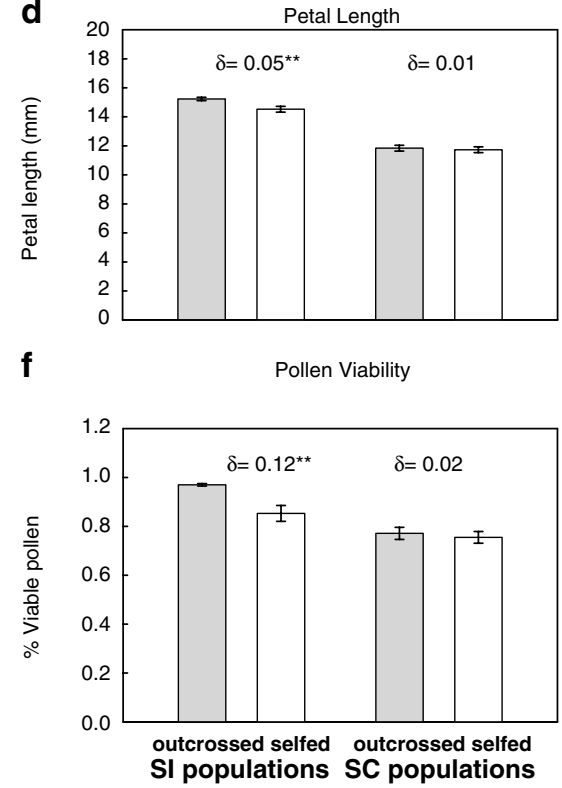

Figure $1(\mathbf{a}-\mathbf{g})$ Mean trait values for outcrossed and selfed offspring in self-incompatible (SI) and self-compatible (SC) populations. Inbreeding depression values $(\delta)$ were tested using orthogonal contrasts of outcrossed and selfed trait values $\left(\right.$ Table $1 ;{ }^{++} P=0.058 ;{ }^{*} P<0.05$; $\left.{ }^{* *} 0.001 P<0.01 ;{ }^{* * *} P<0.001\right)$. Inbreeding depression values equal $1-\left(w_{\mathrm{s}} / w_{\mathrm{o}}\right)$ when selfed offspring had lower trait values than outcrossed progeny and $\left(\mathrm{w}_{\mathrm{o}} / w_{\mathrm{s}}\right)-1$ when trait values of selfed plants exceeded those of outcrossed individuals. Error bars represent $\pm 1 \mathrm{SE}$. 
Table 2 Inbreeding depression in self-incompatible (SI) and selfcompatible (SC) populations

\begin{tabular}{|c|c|c|c|c|}
\hline Trait & Mating system & $\delta$ & Test statistic & $\mathrm{N}$ \\
\hline \multirow[t]{2}{*}{ Germination rate } & SI & $0.37^{* *}$ & $2.929^{a}$ & \\
\hline & SC & -0.01 & $0.457^{\mathrm{a}}$ & 195 \\
\hline \multirow[t]{2}{*}{ Survival rate } & SI & $0.13^{+}$ & $1.535^{\mathrm{a}}$ & \\
\hline & SC & -0.01 & $0.146^{\mathrm{a}}$ & 140 \\
\hline \multirow[t]{2}{*}{ Biomass } & SI & $0.11^{*}$ & 1.707 & 12 \\
\hline & SC & -0.01 & -0.118 & 11 \\
\hline \multirow[t]{2}{*}{ Transition rate to flowering } & SI & 0.02 & 0.832 & \\
\hline & SC & -0.02 & -0.879 & \\
\hline \multirow[t]{2}{*}{ Flower number } & SI & $0.22^{* *}$ & 2.836 & 127 \\
\hline & SC & $0.14^{++}$ & 1.583 & 11 \\
\hline \multirow{2}{*}{ Petal length } & SI & $0.05^{* * *}$ & 3.263 & \\
\hline & SC & 0.01 & 0.377 & \\
\hline \multirow[t]{2}{*}{ Pollen number/anther } & SI & -0.02 & -0.500 & \\
\hline & SC & -0.02 & -0.512 & \\
\hline \multirow[t]{2}{*}{ Pollen viability } & SI & $0.12^{* * *}$ & 3.545 & 12 \\
\hline & SC & 0.02 & 0.464 & \\
\hline \multirow[t]{2}{*}{ Ovule number/flower } & SI & 0.05 & 1.581 & 127 \\
\hline & SC & 0.03 & 0.994 & \\
\hline \multirow[t]{2}{*}{ Lifetime male fitness } & SI & $0.54^{* * *}$ & $3.846^{\mathrm{a}}$ & 239 \\
\hline & SC & 0.15 & $0.432^{\mathrm{a}}$ & \\
\hline \multirow[t]{2}{*}{ Lifetime female fitness } & SI & $0.54^{* * *}$ & $3.817^{a}$ & 240 \\
\hline & $\mathrm{SC}$ & 0.14 & $0.382^{a}$ & $1 \mathrm{c}$ \\
\hline
\end{tabular}

Orthogonal contrasts were used to test the one-sided hypothesis that outcrossed offspring have higher trait values than selfed offspring $\quad\left({ }^{+} P=0.063 ; \quad{ }^{++} P=0.058 ; \quad{ }^{*} P<0.05 ; \quad{ }^{* *} 0.001 \quad P<0.01 ;\right.$ $* * * P<0.001)$

${ }^{a}$ For traits with non-normal distributions, test statistics were calculated from Mann-Whitney $U$ tests of rank difference. $N$ represents the number of families used to generate means.

$\mathrm{df}=112 ; P=0.058$; Table 2 ). Of the remaining 10 traits, observed inbreeding depression values were positive for petal length, pollen viability, ovule number per flower, and estimates of male and female fitness $(0.01<\delta<0.15)$. In contrast, germination rate, survival rate, biomass, flowering rate, and pollen number per anther exhibited slightly negative values of inbreeding depression $(-0.02<\delta<-0.01$; Table 2).

\section{Discussion}

Reductions in the quantity and quality of inbred offspring may prevent the evolution of self-fertilization in self-incompatible populations of L. alabamica. In these populations, $48 \%$ fewer seeds were produced by selffertilization (Table 1), and there was significant inbreeding depression for eight of the 11 traits (Table 2). The relatively large $54 \%$ declines in male and female fitness caused by self-fertilization are consistent with the idea that inbreeding depression may generate and maintain genetically controlled self-incompatibility systems in plants (Charlesworth and Charlesworth, 1979; Lande and Schemske, 1985; Charlesworth, 1988; Lloyd, 1992). In contrast, inbreeding depression was detected for only a
Table 3 Germination and survival of outcrossed and selfed offspring in self-incompatible (SI) and self-compatible (SC) populations

\begin{tabular}{lcccc}
\hline Trait & Mating system & Outcrossed & Selfed & N \\
\hline Germination rate & SI & 0.368 & 0.233 & 240 \\
& SC & 0.236 & 0.238 & 195 \\
Survival rate & SI & 0.794 & 0.688 & 151 \\
& SC & 0.697 & 0.702 & 140 \\
\hline
\end{tabular}

$N$ represents the number of outcrossed and selfed families used to generate means.

single trait in self-compatible populations (Table 2). These results are consistent with a body of data suggesting that self-fertilization purges the genome of strongly deleterious, nearly recessive mutations (Barrett and Charlesworth, 1990; Johnston and Schoen, 1996; Carr and Dudash, 1997; Dudash et al, 1997; Willis, 1999). The fact that inbreeding depression for flower number is present in self-compatible populations is also consistent with the idea that purging should preferentially occur for traits expressed early in life (Husband and Schemske, 1996).

In L. alabamica, the large values of inbreeding depression observed within the large and self-incompatible populations at the center of the species range may help counteract the transmission advantage enjoyed by rare self-compatible genotypes (Charlesworth and Charlesworth, 1979; Uyenoyama et al, 1993). Interestingly, natural selection favoring the transmission of selfcompatible genotypes may be enhanced by the benefits of reproductive assurance in populations at the border of the species range (Barrett et al, 1989; Johnston, 1998; Fausto et al, 2001; Fishman, 2001). In particular, previous work has shown that the appearance of self-compatibility within L. alabamica is often associated with smaller and more marginal glade sites that receive fewer visits by native pollinators (Lloyd, 1965; Solbrig and Rollins, 1977). In these environments where opportunities for cross-fertilization may be limited, self-compatible genotypes may have been favored because of their ability to produce seed autonomously (Baker, 1955, 1967; Lloyd, 1979; Barrett et al, 1989; Burd, 1994; Goodwillie, 2001). If reproductive assurance has favored the evolution of selfcompatibility at the border of the species range in L. alabamica, then reductions in inbreeding depression may likely be caused by the selective removal of partially recessive deleterious alleles in these environments.

Reduced inbreeding depression within self-compatible populations is also consistent with the action of genetic drift in small and/or frequently bottlenecked populations (Wang et al, 1999; Bataillon and Kirkpatrick, 2000; Kirkpatrick and Jame, 2000). If the alleles causing inbreeding depression are strongly deleterious, they will be maintained at extremely low frequencies by natural selection, and thus may be easily lost by drift in effectively small populations that undergo long-distance dispersal or recurrent extinction-recolonization (Barrett et al, 1989; Richards, 2000). In L. alabamica, self-compatible populations may have been established by rare long-distance seed dispersal, and field observations suggest that self-compatible populations go extinct at higher rates (Lloyd, 1965; Busch, personal observation). 
Consequently, it is likely that both natural selection and genetic drift reduce inbreeding depression in the selfcompatible populations of L. alabamica, although the results of this study cannot determine which force has played a more significant role (Dudash and Carr, 2003). Nevertheless, genetic drift has been repeatedly implicated as a major force responsible for reductions in the number of selectively neutral polymorphisms within self-fertilizing populations (Schoen and Brown, 1991; Hamrick and Godt, 1996; Charlesworth, 2003).

A previous study measured inbreeding depression within highly self-compatible populations of the species L. uniflora and L. crassa (Rollins, 1963; Charlesworth et al, 1994). Comparisons between outrossed and selfed progeny in these species suggested a high level of inbreeding depression. In particular, there were 30-41 and $27-49 \%$ reductions in total lifetime fitness caused by self-fertilization in L. uniflora and L. crassa, respectively. These levels of inbreeding depression are similar to those observed within the self-incompatible populations of L. alabamica, although they are much higher than those observed within self-compatible populations of this species (Table 2). The fact that L. uniflora and L. crassa have higher genetic loads compared to the self-compatible populations of L. alabamica may suggest that selffertilization influences inbreeding depression to different extents in closely related plant species (Byers and Waller, 1999).

Alternatively, larger estimates of inbreeding depression within the more highly self-fertilizing species L. uniflora and L. crassa may be the result of differences in the harshness of experimental conditions between studies (Charlesworth et al, 1994). In particular, inbreeding depression was measured within a competitive environment in the experiments with L. uniflora and L. crassa, which generally increases the differences in performance between outcrossed and selfed progeny (Dudash, 1990; Wolfe, 1993; Charlesworth et al, 1994). In light of the ecologically similar habitats experienced by the extant species of Leavenworthia (Rollins, 1963; Lyons and Antonovics, 1991), this issue may be addressed by measuring inbreeding depression in natural populations of self-incompatible and self-compatible taxa. Estimates of inbreeding depression taken from natural populations are required in this and other model systems in order to further understand the effect of deleterious genetic variation on the evolution of plant mating systems (Barrett and Harder, 1996; Byers and Waller, 1999).

\section{Acknowledgements}

I thank my advisor, L Delph, for advice throughout the planning and completion of this project. In addition, I thank my committee members J Bever, C Lively, and M Wade for their comments and suggestions. I Anderson offered valuable help and advice during the location of populations in northern Alabama. I thank C Fuzzell, E Speck, T and M Winchell, and the Willis family for access to their private property. I thank R Davis for work during the experiment. Comments from J Koslow, T Linksvayer, J Moorad, M Neiman, D Waller, and two anonymous reviewers considerably improved the manuscript. This work was supported by Indiana University, the National Science Foundation, Sigma Xi, and the Indiana Academy of Science.

\section{References}

Agren J, Schemske DW (1993). Outcrossing rate and inbreeding depression in two annual monoecious herbs, Begonia hirsuta and B. semivota. Evolution 47: 125-135.

Baker HG (1955). Self-compatibility and establishment after 'long-distance' dispersal. Evolution 9: 347-348.

Baker HG (1967). Support for Baker's law - as a rule. Evolution 21: 853-856.

Barrett SCH, Charlesworth D (1990). Effects of a change in the level of inbreeding on the genetic load. Nature 352: 522-524.

Barrett SCH, Harder LD (1996). Ecology and evolution of plant mating. TREE 11: 73-79.

Barrett SCH, Morgan MT, Husband BC (1989). The dissolution of a complex genetic polymorphism: the evolution of selffertilization in tristylous Eichhornia paniculata (Pontedericaceae). Evolution 43: 1398-1416.

Baskin JM, Webb DH, Baskin CC (1995). A floristic plant ecology study of the limestone glades of northern Alabama. Bull Torrey Bot Club 122: 226-242.

Bataillon T, Kirkpatrick M (2000). Inbreeding depression due to mildly deleterious mutations in finite populations: size does matter. Genet Res 75: 75-81.

Bateman AJ (1955). Self-incompatibility systems in Angiosperms. III. Cruciferae. Heredity 9: 53-68.

Burd M (1994). Bateman's principle and plant reproduction: the role of pollen limitation in fruit and seed set. Bot Rev 60: 83-139.

Byers DL, Waller DM (1999). Do plant populations purge their genetic load? Effects of population size and mating history on inbreeding depression. Ann Rev Ecol Syst 30: 479-513.

Cabin RJ, Evans AS, Jennings DL, Marshall DL, Mitchell RJ, Sher AA (1996). Using bud pollinations to avoid selfincompatibility: implications from studies of three mustards. Can I Bot 74: 285-289.

Campbell RB (1986). The interdependence of mating structure and inbreeding depression. Theor Popul Biol 30: 232-244.

Carr DE, Dudash MR (1996). Inbreeding depression in two species of Mimulus (Scrophulariaceae) with contrasting mating systems. Am J Bot 83: 586-593.

Carr DE, Dudash MR (1997). The effects of five generations of enforced selfing on potential male and female function in Mimulus guttatus. Evolution 51: 1797-1807.

Charlesworth B, Charlesworth D (1999). The genetic basis of inbreeding depression. Genet Res 74: 329-340.

Charlesworth D (1988). Evolution of homomorphic sporophytic self-incompatibility. Heredity 60: 445-453.

Charlesworth D (2003). Effects of inbreeding on the genetic diversity of populations. Proc R Soc Lond B Biol Sci 358: 1051-1070.

Charlesworth D, Charlesworth B (1979). The evolution and breakdown of S-allele systems. Heredity 43: 41-55.

Charlesworth D, Lyons EE, Litchfield LB (1994). Inbreeding depression in two highly inbreeding populations of Leavenworthia. Proc R Soc Lond B Biol Sci 258: 209-214.

Charlesworth D, Morgan MT, Charlesworth B (1990). Inbreeding depression, genetic load, and the evolution of outcrossing rates in a multilocus system with no linkage. Evolution 44: 1469-1489.

Dudash MR (1990). Relative fitness of selfed and outcrossed progeny in a self-compatible, protandrous species, Sabatia angularis L (Gentianaceae) - a comparison in 3 environments. Evolution 44: 1129-1139.

Dudash MR, Carr DE (1998). Genetics underlying inbreeding depression in Mimulus with contrasting mating systems. Nature 393: 682-684.

Dudash MR, Carr DE (2003). Recent approaches into the genetic basis of inbreeding depression in plants. Philos T Roy Soc B 358: 1071-1084.

Dudash MR, Carr DE, Fenster CB (1997). Five generations of enforced selfing and outcrossing in Mimulus guttatus: 
inbreeding depression variation at the population and family level. Evolution 51: 54-65.

Fausto JA, Eckhart VM, Geber MA (2001). Reproductive assurance and the evolutionary ecology of self-pollination in Clarkia xantiana (Onagraceae). Am J Bot 88: 1794-1800.

Fisher RA (1941). Average excess and average effect of a gene substitution. Ann Eugen 11: 53-63.

Fishman L (2001). Inbreeding depression in two populations of Arenaria uniflora (Caryophyllaceae) with contrasting mating systems. Heredity 86: 184-194.

Goodwillie C (2001). Pollen limitation and the evolution of selfcompatibility in Linanthus (Polemoniaceae). Int J Plant Sci 162: $1283-1292$

Hamrick JL, Godt MJW (1996). Effects of life-history traits on genetic diversity in plant species. Philos $T$ Roy Soc B 351: 1291-1298.

Holtsford TP, Ellstrand NC (1990). Inbreeding effects in Clarkia tembloriensis (Onagraceae) populations with different natural outcrossing rates. Evolution 44: 2031-2046.

Husband BC, Schemske DW (1996). Evolution of the magnitude and timing of inbreeding depression in plants. Evolution 46: 216-225.

Jarne P, Charlesworth D (1993). The evolution of the selfing rate in functionally hermaphrodite plants and animals. Ann Rev Ecol Syst 24: 441-466.

Johnston MO (1998). Evolution of intermediate selfing rates in plants: pollination ecology versus deleterious mutations. Genetica 103: 267-278.

Johnston MO, Schoen DJ (1996). Correlated evolution of selffertilization and inbreeding depression: an experimental study of nine populations of Amsinckia (Boraginaceae). Evolution 50: 1478-1491.

Kearns CA, Inouye DW (1993). Techniques for Pollination Biologists. University Press of Colorado: Niwot.

Kirkpatrick M, Jame P (2000). The effects of a bottleneck on inbreeding depression and the genetic load. Am Nat 155: 154-167.

Lande R, Schemske DW (1985). The evolution of self-fertilization and inbreeding depression in plants. I. Genetic models. Evolution 39: 24-40.

Lloyd DG (1965). Evolution of self-compatibility and racial differentiation in Leavenworthia (Cruciferae). Contrib Gray Herb Harv 195: 3-134.

Lloyd DG (1967). The genetics of self-incompatibility in Leavenworthia crassa Rollins (Cruciferae). Genetica 38: 227-242.
Lloyd DG (1979). Some reproductive factors affecting the selection of self-fertilization in plants. Am Nat 113: 67-79.

Lloyd DG (1992). Self-fertilization and cross-fertilization in plants. II. The selection of self-fertilization. Int J Plant Sci 153 370-380.

Lyons EE, Antonovics J (1991). Breeding system evolution in Leavenworthia - breeding system variation and reproductive success in natural populations of Leavenworthia crassa (Cruciferae). Am J Bot 78: 270-287.

Norusis MJ (2000). SPSS 100 Guide to Data Analysis. Prentice Hall: Chicago.

O'Neil P (1997). Natural selection on genetically correlated phenological characters in Lythrum salicaria L. (Lythraceae). Evolution 51: 267-274.

Richards CM (2000). Inbreeding depression and genetic rescue in a plant metapopulation. Am Nat 155: 383-394.

Rollins RC (1963). The evolution and systematics of Leavenworthia (Cruciferae). Contrib Gray Herb Harv 192: 3-98.

Schoen DJ, Brown HD (1991). Intraspecific variation in population gene diversity and effective population size correlates with the mating system in plants. Proc Nat Acad Sci USA 88: 4494-4497.

Sokal R, Rohlf FJ (1995). Biometry, 3rd edn. Freeman WH and Company: New York.

Solbrig OT, Rollins RC (1977). Evolution of autogamy in species of the mustard genus Leavenworthia. Evolution 31: 265-281.

Takebayashi N, Delph LF (2001). An association between a floral trait and inbreeding depression. Evolution 54: 840-846.

Uyenoyama MK, Holsinger KE, Waller DM (1993). Ecological and genetic factors directing the evolution of self-fertilization. Oxf Surv Evol Biol 9: 327-381.

Uyenoyama MK, Waller DM (1991a). Coevolution of selffertilization and inbreeding depression I. Mutation-selection balance at one and two loci. Theor Popul Biol 40: 14-46.

Uyenoyama MK, Waller DM (1991b). Coevolution of selffertilization and inbreeding depression III. Homozygous lethal mutations at multiple loci. Theor Popul Biol 40: 173-210.

Wang J, Hill WG, Charlesworth D, Charlesworth B (1999). Dynamics of inbreeding depression due to deleterious mutations in small populations: mutation parameters and inbreeding rate. Genet Res 74: 165-178.

Willis JH (1999). The role of genes of large effect on inbreeding depression in Mimulus guttatus. Evolution 53: 1678-1691.

Wolfe LM (1993). Inbreeding depression in Hydrophyllum appendiculatum: role of maternal effects, crowding, and parental mating history. Evolution 47: 374-386. 